Bara' S Minwah

BDS, MSc (Assist Lec)

\section{Afrah Kh Al-Hamdany BDS, MSc (Lec)}

Dawood S Allous MBChB, CABS (ENT Spec)

\title{
Orthodontic consequences of airway inadequacy due to adenoids
}

\author{
Department of Oral and Maxilofacial Surgery \\ College of Dentistry, University of Mosul \\ Department of Pedod, Orthod and Prev Dent \\ College of Dentistry, University of Mosul \\ Al-Zahrawi Teaching Hospital \\ Ninevah Health Directorate, Ministry of Health
}

\section{ABSTRACT}

The current study was performed to investigate the possible association between nasopharyngeal airway inadequacy due to enlarged adenoid and some dentoalveoular characteristics in subjects 3-17 years old in Mosul City.

Twenty four patients (12 males and12 females) were randomly selected from patients who admitted to Ear Nose and Throat Department at Al-Zahrawi Teaching Hospital in Mosul City and who indicated for adenoidectomy to relieve severe nasal obstruction. Sixteen variables were recorded and analyzed using Statistical Package for Social Sciences system loaded on Pentium IV computer.

The results proved that a significant correlation existed between nasopharyngeal airway inadequacy due to enlarged adenoid and some dentoalveoular characteristics and females were having high incidence of tonsillar enlargement than males. Key Words: Airway inadequacy, adenoid, malocclusion, nasal obstruction.

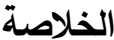

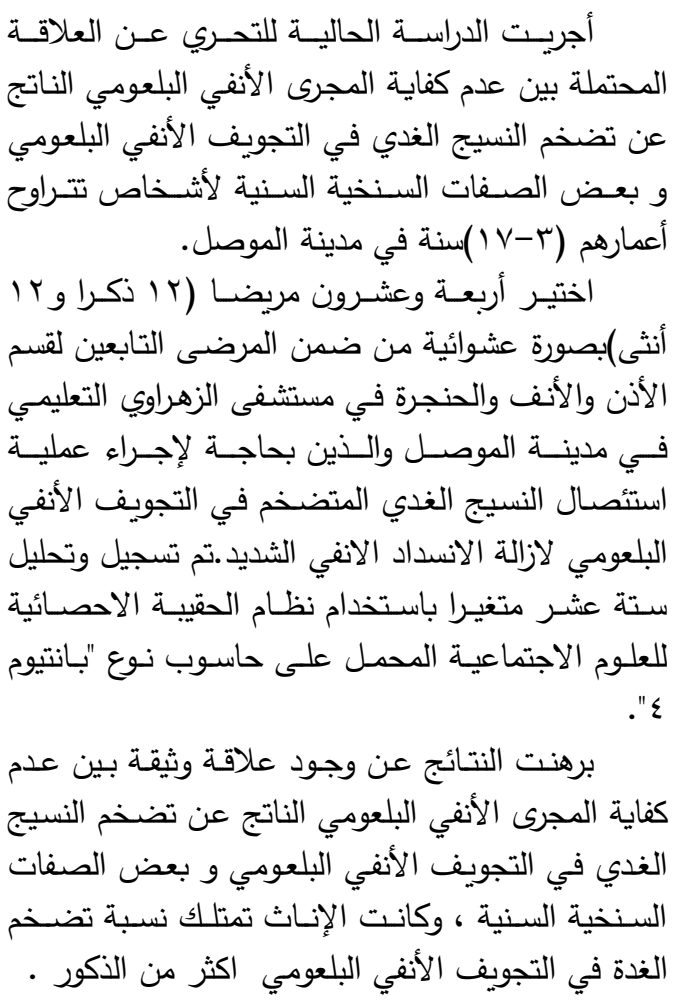

\section{INTRODUCTION}

Studies of the contribution of environment to facial development have demonstrated an association between airway obstruction and undesirable variations in facial form. Human investigations have focused on the contribution of enlarged adenoids, ${ }^{(1-3)}$ allergic rhinitis, ${ }^{(4,5)}$ choanal atresia, ${ }^{(6)}$ enlarged tonsils, ${ }^{(7)}$ adenoid tissue in relation to tongue posture ${ }^{(8)}$ and such surgical interference with the airway as pharyngoplasty. ${ }^{(9)}$
In animals' experiment, Harvold et $a l .^{(10)}$ and Vargervic et al. ${ }^{(10,11)}$ confirmed that environmental impact, such as severe airway obstruction can produce major malocclusion symptoms.

Adenoid is defined as nasopharyngeal tonsil. ${ }^{(12)}$ If this lymphoid tissue becomes so hypertrophied that it produces clinical symptoms, it is defined as adenoid vegetation or adenoid. ${ }^{(13)}$ Adenoid tissues are located in the nasopharynx above the level of soft palate. ${ }^{(13)}$ 
The adenoid gland is poorly developed at birth. It is not visible on plain radiography in infant under the age of one month, but it is clinically identifiable by the age of four months. It is radiographically identifiable in $50 \%$ of infants under 6 month, and can be seen by $\mathrm{x}$-ray in all of them by the age of 6 months. By the age 2 years, hypertrophy and hyperplasia of the adenoid occur, rapid growth from 3 years to 5 years with subsequent decrease in the nasopharyngeal airway, after that the size of adenoid remains relatively constant while the nasopharynx increase in size, so usually the symptoms of adenoid hypertrophy appears at the age of 3-5 years, involution of the adenoid occur, after puberty, so the problem here is the size of adenoid in relation to nasopharynx. ${ }^{(14)}$

The acute infection of adenoid usually follows the upper respiratory tract infection, which result in hyperplasia with multiplication of lymphoid follicles, usually it is associated with acute tonsillitis. ${ }^{(15)}$ There is no doubt that large adenoid can partially or totally obstruct nasal respiration causing snoring, hyponasal speech forcing the child for mouth breathing and nasal discharge and postnasal drip due to sinusitis. ${ }^{(16)}$

Some authors have stressed the importance of adenoidal enlargement as a primary cause of mouth breathing. ${ }^{(17-19)}$ Many studies reported that there is a significant correlation between adenoids and mouth breathing due to the fact that the hypertrophied adenoids occlude the posterior nasopharyngeal breathing space leading to mouth breathing. ${ }^{(20-22)}$ Other studies demonstrated a possible association between airway obstruction and subsequently mouth breathing to undesirable variations in dentofacial form. ${ }^{(23-33)}$

On the other hand, Wenzel et al. ${ }^{(34)}$ noticed no association between mouth breathing and occlusal abnormalities and suggest that such abnormalities have many reasons beyond this habit.

The objective of the present study is to investigate the possible association between nasopharyngeal airway inadequacy due to enlarged adenoid and dentoalveolar characteristics in subjects 3-17 years old in Mosul City.

\section{MATERIALS AND METHODS}

The study subjects were randomly selected from a group of patients who admitted to Ear, Nose and Throat (ENT) Department at Al-Zahrawi Teaching Hospital in Mosul City and indicated for adenoidectomy to relieve severe nasal obstruction; 24 patients (12 males and 12 females) aged 3-17 years.

The sample was assessed by otolaryngologist and oral surgeon. None underwent orthopedic, orthodontic treatment or orthognathic surgery.

Information obtained from the patients included list of questionnaires, sex, age, ENT section (which include: attack of tonsillitis/ year, history of snoring, oral breathing, difficulty in eating or swallowing, grade of obstruction, enlargement of tonsils, nasal mucoal swelling, asthma and perenial rhinitis), dental section (which include: information about the presence or absence of anterior open bite, posterior cross bite, anterior teeth crowding, lip incompetence, in addition to Angle's classification of malocclusion).

Also an assessment of the size of adenoids (post-nasal space) on lateral cephalometric radiograph with a 5-feet focal spot film with neutral position of the head was taken. ${ }^{(35)}$ The clinical impression on the radiography was scored by assessing the adenoid shadow used by Jorma ${ }^{(36)}$ in his study for adenoid in children. He divided the size of adenoid as follows:

I (small): If adenoid shadow obstructing less than $1 / 3$ of the postnasal airway.

II (medium): Less than $2 / 3$ of postnasal airway obstructed by adenoid shadow.

III (large): If the adenoid shadow obstructing more than $2 / 3$ of post-nasal airway.

Descriptive statistics including mean and standard deviation of variables for total sample with comparison between males and females were calculated. Pearson correlation coefficient $(r)$ of variables for total sample with comparison between males and females was carried out to show any statistically significant association between the tested variables. The value of " $\mathrm{r}$ " is described as significant at the level $p \leq 0.05$, and highly significant at the level $p \leq 0.01$. 


\section{RESULTS}

The mean and standard deviation of variables for total sample with comparison between males and females were presented in Table (1) and the Figure. For the ENT section, there was a significant sex difference (at $p \leq 0.05$ ) with the males having higher incidence of difficulty in eating, nasal mucosal swelling and size of adenoids ( $\mathrm{x}$-ray). While the females having higher incidence of attack of tonsillitis/ year, snoring, oral breathing, tonsillar enlargement and history of asthma.
Considering the dental section, a significant sex difference was found (at $p$ $\leq 0.05)$ with the males having higher incidence of anterior deep bite and anterior crowding. While the females having higher incidence of posterior cross bite, lip incompetence and Angle's classification of malocclusion.

Table (2) showed the correlation matrix of all the variables for total sample with comparison between the two sexes. Correlation is considered significant at $p \leq$ 0.05 and highly significant at $p \leq 0.01$.

Table (1): Mean and standard deviation of variables for total sample with comparison between males and females

\begin{tabular}{|c|c|c|c|c|c|c|c|c|}
\hline \multirow{15}{*}{ 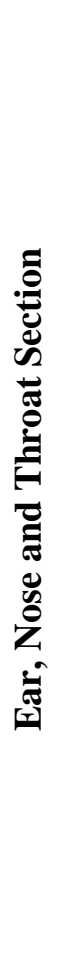 } & Variable & Mean & \pm SD & Sex & Mean & $\pm \mathrm{SD}$ & t-value & Significance \\
\hline & Age & 8.875 & 4.384 & $\begin{array}{l}\mathrm{M} \\
\mathrm{F}\end{array}$ & $\begin{array}{l}7.6667 \\
10083\end{array}$ & $\begin{array}{l}3.359 \\
5.072\end{array}$ & 7.351 & S \\
\hline & Attack of & 11.916 & 6.626 & M & 11.083 & 6.515 & 14.300 & $\mathrm{~S}$ \\
\hline & & & & $\mathrm{M}$ & $\begin{array}{l}12.150 \\
0.667\end{array}$ & $\begin{array}{l}0.911 \\
0.492\end{array}$ & & \\
\hline & Snoring & 0.75 & 0.442 & $\mathrm{~F}$ & 0.833 & 0.389 & 9.004 & S \\
\hline & Oral Breathing & 0.708 & 0.464 & $\begin{array}{l}\mathrm{M} \\
\mathrm{F}\end{array}$ & $\begin{array}{l}0.750 \\
0.667\end{array}$ & $\begin{array}{l}0.452 \\
0.492\end{array}$ & 17.07 & S \\
\hline & Grade of & 1.333 & 0.482 & $\mathrm{M}$ & 1.333 & 0.492 & 0.000 & NS \\
\hline & Obstruction & & & $\mathrm{F}$ & 1.333 & 0.492 & & \\
\hline & $\begin{array}{l}\text { Difficulty in } \\
\text { Eating }\end{array}$ & 0.625 & 0.495 & $\begin{array}{c}\mathrm{M} \\
\mathrm{F}\end{array}$ & $\begin{array}{l}0.750 \\
0.500\end{array}$ & $\begin{array}{l}0.452 \\
0.522\end{array}$ & 5.000 & S \\
\hline & Tonsillar & 0833 & 0381 & $\mathrm{M}$ & 0.750 & 0.452 & 9998 & $S$ \\
\hline & Enlargement & 0.833 & 0.381 & $\mathrm{~F}$ & 0.917 & 0.289 & 9.998 & $\mathrm{~S}$ \\
\hline & $\begin{array}{l}\text { Nasal Mucosal } \\
\text { Swelling }\end{array}$ & 0.375 & 0.495 & $\begin{array}{l}\mathrm{M} \\
\mathrm{F}\end{array}$ & $\begin{array}{l}0.500 \\
0.250\end{array}$ & $\begin{array}{l}0.532 \\
0.452\end{array}$ & 3.000 & S \\
\hline & & & & M & 0.167 & 0.389 & & \\
\hline & Asthma & 0.125 & 0.338 & $\mathrm{~F}$ & 0.083 & 0.289 & 1.041 & S \\
\hline & $\begin{array}{l}\text { Adenoids } \\
\text { (x-ray) }\end{array}$ & 0.375 & 0.495 & $\begin{array}{l}\mathrm{M} \\
\mathrm{F}\end{array}$ & $\begin{array}{l}0.417 \\
0.333\end{array}$ & $\begin{array}{l}0.515 \\
0.492\end{array}$ & 8.993 & S \\
\hline \multirow{10}{*}{ 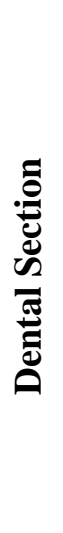 } & Anterior Deep & 4.167 & 0.204 & $\mathrm{M}$ & 8.333 & 0.289 & 1.000 & $\mathrm{~S}$ \\
\hline & Bite & & & $\mathrm{F}$ & 0.000 & $0.000^{(a)}$ & & \\
\hline & Anterior Open & 0.5 & 0.511 & $\mathrm{M}$ & 0.500 & 0.522 & 0.000 & NS \\
\hline & Bite & & & $\mathrm{F}$ & 0.500 & 0.522 & & \\
\hline & $\begin{array}{l}\text { Posterior Cross } \\
\text { Bite }\end{array}$ & 0.333 & 0.482 & $\begin{array}{l}\mathrm{M} \\
\mathrm{F}\end{array}$ & 0.250 & $\begin{array}{r}0.452 \\
0.515\end{array}$ & 3.999 & $\mathrm{~S}$ \\
\hline & Anterior & & & $\mathrm{M}$ & & 0.515 & & \\
\hline & Crowding & 0.375 & 0.495 & $\mathrm{~F}$ & 0.333 & 0.492 & 8.993 & S \\
\hline & Lip & 0583 & 05 & $\mathrm{M}$ & 0.500 & 0.522 & 6999 & S \\
\hline & Incompetence & 0.00 & 0.504 & $\mathrm{~F}$ & 0.667 & 0.492 & טצי & \\
\hline & Angle's & 1.25 & 0.442 & M & $\begin{array}{l}1.083 \\
1.417\end{array}$ & $\begin{array}{l}0.289 \\
0.515\end{array}$ & 7.499 & $\mathrm{~S}$ \\
\hline
\end{tabular}

M: Males $(\mathrm{n}=12)$; F: Females $(\mathrm{n}=12)$; SD: Standard deviation.

$\mathrm{NS}=$ Not significant; $\mathrm{S}=$ Significant at $p \leq 0.05$.

(a) Can not be computed because the standard deviation is zero. 


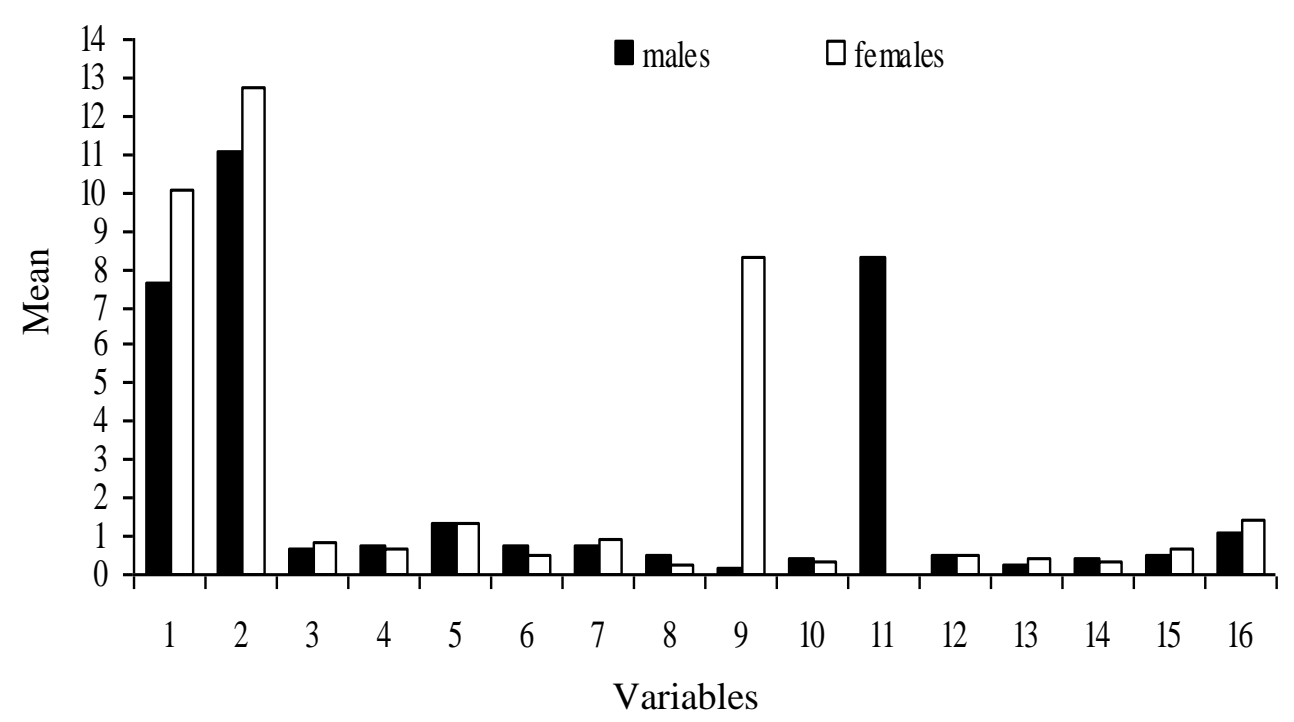

1. Age

2. Attack of tonsillitis

3. Snoring

4. Oral breathing
5. Grade of obstruction

6. Difficulty in eating

7. Tonsillar enlargement

8. Nasal mucosal swelling
9. Asthma

10. Adenoids (x-ray)

11. Anterior deep bite

12. Anterior open bite
13. Posterior cross bite

14. Anterior crowding

15. Lip incompetence

16. Angle's classification

Figure: The comparison of the mean between males and females for different variables

\section{DISSCUSION}

The results of this study must be interpreted with the realization that this sample comprises a wide spectrum of developmental stages of dental occlusion (317years).

In view of the difference between girls and boys, a significant sex difference has been found for the following variables: Difficulty in eating, nasal mucosal swelling and size of adenoids ( $\mathrm{x}$-ray), with the males having higher value. Whereas the females having higher incidence of attack of tonsillitis/year, snoring, oral breathing, tonsillar enlargement and history of asthma.

For dental parameters, the males have significant higher incidence of anterior deep bite and anterior crowding. While the females having significant higher incidence of posterior cross bite, lip incompetence and more tendencies toward Class II Angle's classification of malocclusion. Mouth breathing is believed to be primary factor in developing Class II division 1 malocclusion. ${ }^{(23)}$ Ung et al. ${ }^{(24)}$ Found weak tendency among mouth breathers towards Class II division 1 malocclusion. LinderAronson ${ }^{(37)}$ stated that there is a normal anteroposterior relationship between upper and lower jaws in adenoid children.

The females having significant higher incidence of posterior cross bite. This is in accordance with Limme ${ }^{(27)}$ and Oulis et $a l .{ }^{(31)}$

Many invistigators ${ }^{(4,34)}$ have demonstrated relationships between atopy and dentofacial growth.

Regarding the relation between nasopharyngeal airway inadequacy and dentofacial growth, including development of occlusion, there is a positive correlation between attack of tonsillitis and difficulty in eating; snoring and oral breathing and tonsillar enlargement. Several authors have stressed the importance of adenoidal enlargement as a primary cause of mouth breathing. ${ }^{(17-19)}$ Many studies ${ }^{(20-22)}$ reported that there is a significant correlation between adenoids and mouth breathing due to the fact that the hypertrophied adenoids occlude the posterior nasopharyngeal breathing space leading to mouth breathing. There is no doubt that large adenoid partially or totally obstruct the nasal respiration causing snoring, hyponasal speech forcing the child for mouth breathing, nasal discharge and post-nasal drip due to sinusitis. $^{(16)}$ 
Table (2): Pearson correlation coefficient of variables for total sample with comparison between males and females

\begin{tabular}{|c|c|c|c|c|c|c|c|c|c|}
\hline Variable & Sex & 1 & 2 & 3 & 4 & 5 & 6 & 7 & 8 \\
\hline 1 & $\begin{array}{l}\mathbf{M} \\
\mathbf{F} \\
\mathbf{T}\end{array}$ & & & $\begin{array}{l}-.729^{* *} \\
-.465^{*}\end{array}$ & & & & $-.74^{* *}$ & $.811^{* * *}$ \\
\hline 2 & $\begin{array}{l}\mathbf{M} \\
\mathbf{F} \\
\mathbf{T} \\
\end{array}$ & & & & & & $\begin{array}{l}-.843^{* *} \\
-.448^{*} \\
\end{array}$ & & \\
\hline 3 & $\begin{array}{l}\mathbf{M} \\
\mathbf{F} \\
\mathbf{T}\end{array}$ & $\begin{array}{l}-.729^{* * *} \\
-.465^{*}\end{array}$ & & & $\begin{array}{l}.816^{* *} \\
.476^{*}\end{array}$ & & & $.672^{*}$ & \\
\hline 4 & $\begin{array}{l}\mathbf{M} \\
\mathbf{F} \\
\mathbf{T} \\
\end{array}$ & & & $\begin{array}{l}.816^{* *} \\
.476^{*}\end{array}$ & & & & & $-.557^{*}$ \\
\hline 5 & $\begin{array}{l}\mathbf{M} \\
\mathbf{F} \\
\mathbf{T}\end{array}$ & & & & & & & & \\
\hline 6 & $\begin{array}{l}\mathbf{M} \\
\mathbf{F} \\
\mathbf{T} \\
\end{array}$ & & $\begin{array}{c}-.843^{* *} \\
.448^{*} \\
\end{array}$ & & & & & 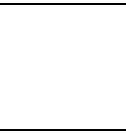 & \\
\hline 7 & $\begin{array}{l}\mathbf{M} \\
\mathbf{F} \\
\mathbf{T}\end{array}$ & $-.74^{* *}$ & & $.674^{*}$ & & & & & $.577^{*}$ \\
\hline 8 & $\begin{array}{l}\mathbf{M} \\
\mathbf{F} \\
\mathbf{T}\end{array}$ & & & & $-.557^{*}$ & & & $.577^{*}$ & \\
\hline 9 & $\begin{array}{l}\mathbf{M} \\
\mathbf{F} \\
\mathbf{T}\end{array}$ & $.811^{* *}$ & & $-.632^{*}$ & & & & & $.467^{*}$ \\
\hline 10 & $\begin{array}{l}\mathbf{M} \\
\mathbf{F} \\
\mathbf{T}\end{array}$ & & & & & & & & $.674^{*}$ \\
\hline 11 & $\begin{array}{l}\mathbf{M} \\
\mathbf{F} \\
\mathbf{T}\end{array}$ & $.781^{*}$ & & & & & & $-.466^{*}$ & \\
\hline 12 & $\begin{array}{l}\mathbf{M} \\
\mathbf{F} \\
\mathbf{T}\end{array}$ & $.051^{* *}$ & & & & & & & \\
\hline 13 & $\begin{array}{l}\mathbf{M} \\
\mathbf{F} \\
\mathbf{T}\end{array}$ & & & & & & $-.548^{* *}$ & & \\
\hline 14 & $\begin{array}{l}\mathbf{M} \\
\mathbf{F} \\
\mathbf{T} \\
\end{array}$ & $.666^{*}$ & & & & $.625^{*}$ & & & \\
\hline 15 & $\begin{array}{l}\mathbf{M} \\
\mathbf{F} \\
\mathbf{T}\end{array}$ & & & & & & & & \\
\hline 16 & $\begin{array}{l}\mathbf{M} \\
\mathbf{F} \\
\mathbf{T}\end{array}$ & & & & & & & & \\
\hline
\end{tabular}

To be continued........ 


\begin{tabular}{|c|c|c|c|c|c|c|c|c|c|}
\hline Variable & Sex & 9 & 10 & 11 & 12 & 13 & 14 & 15 & 16 \\
\hline 1 & $\begin{array}{l}\mathbf{M} \\
\mathbf{F} \\
\mathbf{T}\end{array}$ & $.811^{* *}$ & & $.781^{* *}$ & $.051^{* * *}$ & & $.666^{*}$ & & \\
\hline 2 & $\begin{array}{l}\mathbf{M} \\
\mathbf{F} \\
\mathbf{T}\end{array}$ & 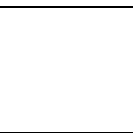 & & & & & & & \\
\hline 3 & $\begin{array}{l}\mathbf{M} \\
\mathbf{F} \\
\mathbf{T}\end{array}$ & $-.632^{*}$ & & & & & & & \\
\hline 4 & $\begin{array}{l}\mathbf{M} \\
\mathbf{F} \\
\mathbf{T}\end{array}$ & & & & & & & & \\
\hline 5 & $\begin{array}{l}\mathbf{M} \\
\mathbf{F} \\
\mathbf{T}\end{array}$ & & & & & & $.625^{*}$ & & \\
\hline 6 & $\begin{array}{l}\mathbf{M} \\
\mathbf{F} \\
\mathbf{T}\end{array}$ & & & & & $\begin{array}{l}-.548^{* * *} \\
\end{array}$ & & & \\
\hline 7 & $\begin{array}{l}\mathbf{M} \\
\mathbf{F} \\
\mathbf{T}\end{array}$ & & & $-.466^{*}$ & & & & & \\
\hline 8 & $\begin{array}{l}\mathbf{M} \\
\mathbf{F} \\
\mathbf{T}\end{array}$ & & $.467^{*}$ & $.674^{*}$ & & & & & \\
\hline 9 & $\begin{array}{l}\mathbf{M} \\
\mathbf{F} \\
\mathbf{T}\end{array}$ & & & $\begin{array}{l}.607^{*} \\
.552^{* *}\end{array}$ & & & & & \\
\hline 10 & $\begin{array}{l}\mathbf{M} \\
\mathbf{F} \\
\mathbf{T}\end{array}$ & & & & & $-.598^{*}$ & $.666^{*}$ & & \\
\hline 11 & $\begin{array}{l}\mathbf{M} \\
\mathbf{F} \\
\mathbf{T} \\
\end{array}$ & $\begin{array}{l}.607^{*} \\
.552^{* *}\end{array}$ & & & & & & & \\
\hline 12 & $\begin{array}{l}\mathbf{M} \\
\mathbf{F} \\
\mathbf{T}\end{array}$ & & & & & & & & \\
\hline 13 & $\begin{array}{l}\mathbf{M} \\
\mathbf{F} \\
\mathbf{T}\end{array}$ & & $-.598^{*}$ & & & & & & \\
\hline 14 & $\begin{array}{l}\mathbf{M} \\
\mathbf{F} \\
\mathbf{T}\end{array}$ & & & & & & & & \\
\hline 15 & $\begin{array}{l}\mathbf{M} \\
\mathbf{F} \\
\mathbf{T}\end{array}$ & & & & & & & & $\begin{array}{l}.598^{*} \\
.488^{*}\end{array}$ \\
\hline 16 & $\begin{array}{l}\mathbf{M} \\
\mathbf{F} \\
\mathbf{T}\end{array}$ & & & & & & & $\begin{array}{l}.598^{*} \\
.488^{*}\end{array}$ & \\
\hline
\end{tabular}

M: Males (n=12); F: Females ( $\mathrm{n}=12)$.

*Correlation is significant at the level $p \leq 0.05$.

** Correlation is highly significant at the level $p \leq 0.01$.

1. Age 5. Grade of obstruction 9. Asthma

2. Attack of tonsillitis 6. Difficulty in eating

3. Snoring

4. Oral breathing
7. Tonsillar enlargement

8. Nasal mucosal swelling
9. Asthma

10. Adenoids ( $\mathrm{x}$-ray)

11. Anterior deep bite

12. Anterior open bite
13. Posterior cross bite

14. Anterior crowding

15. Lip incompetence

16. Angle's classification 
The most important finding of this study is that a significant positive correlation (at 0.05 level) existed between the grade of obstruction, adenoid in $\mathrm{x}$-ray and the anterior dental crowding. This is in accordance with Linder-Aronson et al., ${ }^{(2)}$ and Woodside et $a l .{ }^{(3)}$ Several investigators $^{(39)}$ found that adenoidectomy and changed mode of breathing are associated with significant labial positioning of incisor teeth in both jaws during 5 years after surgery. Linder-Aronson ${ }^{(40)}$ reported that maxillary and mandibular incisors changed from retroclined to a proclined position during the first year after adenoidectomy, implying an environmental changes in tooth position. Woodside et $a l .{ }^{(3)}$ found that mandibular incisors were statistically very significant and more crowded in group with nasal airway obstruction than in controls.

In contrast, Hannuksela and Vaananen ${ }^{(38)}$ reported no significant mandibular incisor crowding.

A negative correlation was found between tonsillar enlargement and anterior deep bite, a positive significant correlation was found between nasal mucosal swelling and anterior deep bite and a positive correlation was found between asthma, perenial rhinitis and anterior deep bite. This comes in agreement with Bauman and Plinkert, ${ }^{(22)}$ Shapira ${ }^{(41)}$ who showed a correlation between obstructed nasal breathing, large adenoids and vertical growth pattern of the face. Also other authors $\left.{ }^{(4,} 24,26-29\right)$ found that mouth breathing is associated with increased anterior facial height. The increase in anterior facial height in adenoid children is due to dorsal rotation of mandible caused by soft tissue stretching. ${ }^{(17)}$ Principato $^{(30)}$ found that the increase in anterior facial height is due to excessive molar tooth eruption and consequently a clockwise rotation of the growing mandible. Takashi and Ishiwata, ${ }^{(42)}$ in there experimental study, suggested that the elevator muscle, masseter, electromyographic activity is inhibited during oral respiration.

\section{CONCLUSIONS}

A significant correlation existed between nasopharyngeal airway inadequa- cy due to enlarged adenoid and some dentoalveoular characteristics.

Females had high incidence of tonsillar enlargement than males.

\section{REFERENCES}

1. Dunn GF, Green LJ, Cunatt JJ. Relationship between variation of mandibular morphology and variation of nasopharyngeal airway size in monozygotic twins. Angle Orthod. 1973; 43: 129-135.

2. Linder-Aronson S, Woodside DG, Lundstrom A. Mandibular growth direction following adenoidectomy. Am J Orthod Dentofac Orthop. 1986; 89: 273-284.

3. Woodside DG, Linder-Aronson S, Lundstrom A, McWilliam J. Mandibular and maxillary growth after changed mode of breathing. Am J Orthod Dentofac Orthop. 1991; 100:1-18.

4. Bresolin D, Sharpiro PA, Sharpiro GC, Chaptko MK, Dassel S. Mouth breathing in children: Its relationship to dentofacial development. Am J Orthod.1983; 83: 334-340.

5. Woodside DS, Linder-Aronson S, Stubbs DO. Relationship between mandibular incisor crowding and nasal mucosal swelling. Proc Finn Dent Soc. 1991; 8: 127-138.

6. Freng A. Dentofacial development in long-lasting nasal stenosis. Scand J Dent Res. 1979; 87: 260-267.

7. Behelfelt K, Linder-Aronson S. The effect of enlarged tonsils and tonsillectomy on the dentition and facial skeleton. Swed Dent J. 1990; 42: 67-71.

8. Adamidies IP, Spyropoulos MN. The effects of lymphadenoid hypertrophy on the position of the tongue, the mandible and the hyoid bone. Eur J Orthod.1983; 5: 279-294.

9. Long RE, McNamara JA. Facial growth following pharyngeal flap surgery: Skeletal assessment on serial lateral cephalometric radiographs. Am J Orthod. 1985; 87: 187-196.

10. Harvold EP, Vagervik L, Chierici G. Primate experiments on oral respiration. Am J Orthod Dentofac Orthop. 1981; 89: 359-372.

11. Vargervik K, Miller AJ, Chierici G, Harvold EP, Tomer B. Morphologic 
response to changes in neuromuscular patterns experimentally induced by altered mode of respiration. Am J Orthod. 1984; 85: 115-124.

12. Cowan DL, Hibbert J. Sleep apnea syndrome. In: Adams DA. Scott-Brown's Otolaryngology. Paediatrics Otolaryngology. $6^{\text {th }}$ ed. Butterworth Heinemann .1997; Pp: 5-8.

13. Handelman CS, Osborne G. Growth of the nasopharynx and adenoid development from one to eighteen years. Angle Orthod. 1976; 46: 243-259.

14. Chuan C, Tiech L. Nasopharynx. In: Hibbert J. Scott-Brown's Otolaryngology. Laryngology. $6^{\text {th }}$ ed. Butterworth Heinemann. 1997; Pp: 4-6.

15. Bailey CM, Croft CB. Tonsil and Adenoid. In: Adams DA. Scott-Brown's Otolaryngology. Pediatrics Otolaryngology. $6^{\text {th }}$ ed. Butterworth Heinemann. 1997; Pp: 4-6.

16. Cowson R, Gleeson M. Anatomy of the Pharynx. In: Gleeson M. Scott-Brown's Otolaryngology Basic Sciences. $6^{\text {th }}$ ed. Butterworth Heinemann. 1997; Pp: 9-10.

17. Kerr WJ, Mc William JS, LinderAronson S. Mandibular form and position related changed mode of breathing. A five year longitudinal study. Angle Orthod. 1989; 59: 91-96.

18. Cantarella G, De Bert G. Evaluation of chronic nasal respiratory obstruction in children using fiberoptic rhinopharyngoscopy and rhinomanometry. Acta Otorhinol Ital. 1990; 10: 59.

19. Tourne LP. Growth of the pharynx and its physiologic implications. Am J Orthod. 1991; 99: 129-139.

20. Subtenly JD. Oral respiration, facial maldevelopment and corrective dentofacial orthopedics. Angle Orthod. 1980; 50: 147-164.

21. Khurana AS, Arora MML, Gaginder S. Relationship between adenoids and malocclusion. Plainmetric study. $J$ Ind Dent Assoc. 1986; 58: 143-146.

22. Baumann I, Plinkert PK. Effect of breathing mode and nose ventilation on growth of the facial bones. HNO.1996; 44(5): 229-234.

23. Graber TM. Orthodontics: Principles and Practice. $1^{\text {st }}$ ed. WB Saunders Co. Philadelphia. 1988.
24. Ung U, Koenig J, Shapira G, Trask G. A quantitative assessment of respiratory patterns and their effect on dentofacial development. Am J Orthod Dentofac Orthop.1990; 98: 523-532.

25. Tourne LP. The long face syndrome and impairment of the nasopharyngeal airway. Angle Orthod. 1990; 60: 167-176.

26. Hassan F. The relation between nasopharyngeal airway and dentofacial structures (A cephalometric study). MSc thesis. College of Dentistry. University of Baghdad. 1990.

27. Limme M. Orthodontic consequences of mouth breathing. Rev Belge Med Dent. 1990; 46: 36-50.

28. Limme M. Orthognathic and orthodontic consequences of mouth breathing. Acta Otorhinolaryngol Belg. 1993; 47: 154155.

29. Limme M. Orthodontic studies in mouth breathing. Acta Otorhinolaryngol Belg. 1993; 47: 197-208.

30. Principato JJ. Upper airway obstruction and craniofacial morphology. Otolaryngol Tlead Neck Surg. 1991; 104: 881890.

31. Oulis CJ, Vadiakas GP, Ekonomides J. The effect of hypertrophic adenoids and tonsils on the development of posterior cross bite and oral habits. J Clin Pediatr Dent. 1994; 18(3): 197-201.

32. Zainul-Abedin W. Dentofacial morphology of patients with nasopharyngeal airway inadequacy due to enlarged adenoids. MSc thesis. College of Dentistry. University of Baghdad. 1999.

33. Ali SM. Role and relation of pharyngeal length, depth and height to some morphological features in anterior open bite subjects age of 10-17 years (A cephalometric cross-sectional study). MSc thesis. College of Dentistry. University of Baghdad. 2000.

34. Wenzel A, Hojensgaard E, Henrikson J. Craniofacial morphology and head posture in children with asthma and perenial rhinitis. Eur J Orthod. 1987; 7: 83-92.

35. Al-Nakshabandi AS. A comparative study of clinical and radiological assessments of adenoid enlargement. A fellowship thesis. College of Medicine. Mosul University. 1998. 
36. Jorma JH. Adenoid in schoolage children. J Laryngol Otol. 1995; 3: 196200.

37. Linder-Aronson S. Adenoids: Their effect on mode of breathing and nasal airflow and their relationship to characteristics of the facial skeleton and the dentition. Acta Otorhinolaryngol (Stockh). 1970; 1: 265.

38. Hannuksela A, Vaananen A. Predisposing factors for malocclusion in 7years-old children with special reference to atopic diseases. Am J Orthod. 1987; 92: 299-303.

39. Linder-Aronson S, Woodside DG, Hell- sing E, Emerson W. Normalization of incisor position after adenoidectomy. Am J Orthod Dentofac Orthop. 1993; 103: 412-427.

40. Linder-Aronson S. Effects of adenoidectomy on dentition and nasopharynx. Am J Orthod. 1974; 65: 1-15.

41. Shapira GG. Effect of nasal obstruction on facial development. J Allergy Clin Immunol. 1988; 81: 967-971.

42. Takashi ON, Ishiwata YD. Inhibition of masseteric electromyographic activity during oral respiration. Am J Orthod Dentofac Orthop. 1998; May: 518-525. 